\title{
Evaluation of Clinical Features and Prognosis in COVID-19 Patients with Hypertension: A Single-center Retrospective Observational Study
}

\author{
Hipertansiyonu Olan COViD-19 Hastalarında Klinik Özelliklerin ve Prognozun \\ Değerlendirilmesi: Tek Merkezli Retrospektif Gözlemsel Çalışma
}

(D) Gülay OKAY1, (D) Bülent DURDU1, id Yasemin AKKOYUNLU11, iD Sibel BÖLÜKÇÜ1, iD Asiye Bahar KAÇMAZ²,

(i) Bilge SÜMBÜL³ , id Hatice Dilara KARAKUŞ1, id Meliha Meriç KOÇ1

${ }^{1}$ Bezmialem Vakıf University Faculty of Medicine, Department of Infectious Diseases and Clinical Microbiology, İstanbul, Türkiye

${ }^{2}$ Bezmialem Vakıf University Dragos Hospital, Department of Infectious Diseases and Clinical Microbiology, İstanbul, Türkiye

${ }^{3}$ Bezmialem Vakıf University Faculty of Medicine, Department of Medical Microbiology, İstanbul, Türkiye

\begin{abstract}
Objective: The aim of this study is to investigate the effect of hypertension on the clinical severity and prognosis of Coronavirus disease-2019 (COVID-19) patients.

Methods: In this retrospective observational study, reverse transcription-polymerase chain reaction (RT-PCR) positive COVID-19 patients over the age of 18 years who were hospitalized in Bezmialem Vakıf University between March and May 2020 were included. The patients were divided into two groups as hypertensive and non-hypertensive and compared for clinical, laboratory and prognosis.

Results: Two hundred sixty COVID-19 patients were included in the study, $55.4 \%$ of them were male and the mean ( \pm standard deviation) age was $54.1 \pm 15.5$ years. Hypertensive patients were older $(64.6 \pm 11.5$ and $47.2 \pm 13.9)(\mathrm{p}<0.001)$, had higher diabetes mellitus rates $(41.7 \%$ and $11.5 \%, \mathrm{p}<0.001)$ and more complicated with chronic renal failure $(16.5 \%$ vs. $2.5 \%$, p<0.001). While $56.1 \%$ of patients were desaturated in the hypertensive group $\left(\mathrm{SaPO}_{2}<93 \%\right)$, this rate was $32.3 \%$ in the group without hypertension $(\mathrm{p}<0.001)$. While oxygen therapy was needed in $39.8 \%$ of hypertensive patients, this rate was $25.5 \%$ in non-hypertensive patients $(\mathrm{p}=0.001)$. The rate of transfer to intensive care unit $(23.3 \%)$ and in-hospital mortality rate $(17.5 \%)$ in hypertensive patients were higher than
\end{abstract}

\section{ÖZ}

Amaç: $\mathrm{Bu}$ çalışmada amacımız, hipertansiyonun Koronavirüs hastalığı-2019 (COVİD-19) hastalarının klinik ağıllığı ve prognozu üzerine etkisini araştırmaktır.

Yöntemler: Bu retrospektif gözlemsel çalışmaya Mart-Mayıs 2020 tarihleri arasında Bezmialem Vakıf Üniversitesi Hastanesi'nde yatarak izlenen 18 yaş üstü, ters transkripsiyon-polimeraz zincir reaksiyonu (RT-PCR) pozitif COVID-19 hastalar dahil edildi. Hastalar hipertansif ve hipertansif olmayan olarak iki gruba ayrılarak klinik, laboratuvar ve prognoz açısından karşılaştırıldı.

Bulgular: Çalışmaya dahil edilen 260 COVİD-19 hastasının $\% 55,4$ 'ü erkek, yaş ortalamaları ( \pm standart sapma) $54,1 \pm 15,5^{\prime}$ tir. Hipertansif hastalar daha yaşlıydı $(64,6 \pm 11,5$ ve $47,2 \pm 13,9)$ $(\mathrm{p}<0,001)$, daha yüksek diabetes mellitus oranlarına sahipti (\%41,7 ve \%11,5, p<0,001) ve kronik böbrek yetmezliği ile daha fazla komplike idi $(\% 16,5$ 'e karşı $\% 2,5, \mathrm{p}<0,001)$. Hipertansiyon olan grupta hastaların \%56,1'i desatüre olurken $\left(\mathrm{SaPO}_{2}<\% 93\right)$, hipertansiyon olmayan grupta bu oran $\% 32,3$ idi $(\mathrm{p}<0,001)$. Hipertansif hastaların \%39,8'inde oksijen tedavisine ihtiyaç olmuşken, hipertansif olmayan hastalarda bu oran $\% 25,5$ idi $(\mathrm{p}=0,001)$. Hipertansif hastalarda yoğun bakım ünitesine yatış oranı $(\% 23,3)$ ve hastane içi mortalite oranı $(\% 17,5)$, hipertansif
Address for Correspondence: Gülay OKAY, Bezmialem Vakıf University Faculty of Medicine, Department of Infectious Diseases and Clinical Microbiology, İstanbul, Türkiye

E-mail: gulay.okay@hotmail.com ORCID ID: orcid.org/0000-0003-1616-2162

Cite this article as: Okay G, Durdu B, Akkoyunlu Y, Bölükçü S, Kaçmaz AB, Sümbül B, Karakuş HD, Koç MM. Evaluation of Clinical Features and Prognosis in COVID-19 Patients with Hypertension: A Single-center Retrospective Observational Study. Bezmialem Science 2020;8(Supplement 2):15-21.
Received: 25.06 .2020

Accepted: 04.06.2020 
those in non-hypertensive patients ( $11.5 \%$ and $8.8 \%$, respectively) $(\mathrm{p}=0.01$ and $\mathrm{p}=0.025)$.

Conclusion: Our study shows that additional attention should be paid to prevent poor prognosis in COVID-19 patients with hypertension.

Keywords: COVID-19, hypertension, Severe Acute Respiratory Syndrome Coronavirus-2, prognosis olmayan hastalardaki oranlara göre yüksekti (sırasıyla $\% 11,5$ ve $\% 8,8)(\mathrm{p}=0,01$ ve $\mathrm{p}=0,025)$.

Sonuç: Çalışmamız hipertansiyonu olan COVID-19 hastalarında kötü prognozu önlemek için ek dikkat göstermek gerektiğini göstermektedir.

Anahtar Sözcükler: COVİD-19, hipertansiyon, Şiddetli Akut Solunum Sendromu Coronavirus-2, prognoz

\section{Introduction}

As of December 2019, pneumonia patients infected by a new type of coronavirus were detected consecutively in Wuhan City, Hubei State of China. This new type of coronavirus was later named Severe Acute Respiratory Syndrome Coronavirus-2 (SARS-CoV-2) by the International Virus Taxonomy Committee (1). And then, the disease was named Coronavirus disease-2019 (COVID-19) by the World Health Organization (WHO) (2).

It has been reported in epidemiological studies of COVID-19 patients that hypertension (HT) carries an increased risk for poor prognosis $(1,3,4)$. Angiotensin-converting enzyme (ACE2) is considered as the receptor for the entry of SARS-CoV-2 into human cells. $(5,6)$. The ACE2 receptor is widely found in various organ systems in the human body, including the respiratory system and cardiovascular system $(7,8)$. In studies, HT has been reported as one of the most common comorbid diseases seen in patients with COVID-19 $(9,10)$. In one study, it has been shown that SARS-CoV-2 binds to the host ACE2 receptor via the $S$ protein (11). Due to the relationship between SARS-CoV-2 and ACE2 and the role of ACE2 in HT pathogenesis, the issue of whether HT plays a role in the pathogenesis of COVID-19 is controversial. In some studies, it has not been revealed that HT is related to disease severity (12). Therefore, it remains unclear whether HT is a risk factor for COVID-19.

In this study, our aim is to compare the clinical and laboratory characteristics of COVID-19 patients with and without HT in order to determine the effect of HT on the severity of COVID-19 and prognosis.

\section{Method}

\section{Study Design and Patient Population}

This retrospective observational study was approved by the Bezmialem Vakıf University Ethics Committee. Reverse transcription-polymerase chain reaction (RT-PCR) positive COVID-19 patients over the age of 18 years who were hospitalized in Bezmialem Vakıf University Hospital between March and May 2020 were included in the study. The diagnosis and treatment of the patients included in the study were made in accordance with the WHO, Ministry of Health, COVID-19 diagnosis and treatment guidelines. The patients were divided into two groups as those with and without HT according to their medical history and compared in terms of clinical, laboratory features, clinical results and mortality.
The diagnosis of COVID-19 was made by evaluating the following criteria: 1) History of contact with a COVID-19 patient, 2) Fever or other respiratory symptoms, 3) Typical viral pneumonia findings in computed tomography (CT) imaging 4) Positive SARS-CoV-2 RNA with RT-PCR. The patients were clinically divided into four groups as mild, moderate, severe and critical according to the classification of WHO (2). 1) Mild: Patients with symptoms but no signs of viral pneumonia and hypoxia, 2) Moderate: Those with clinical symptoms of pneumonia (fever, cough, shortness of breath, rapid breathing) but with $\mathrm{SpO}_{2} \geq 90 \%$ in room temperature, without signs of severe pneumonia, 3) Severe: Clinical signs of pneumonia (fever, cough, dyspnea, rapid breathing) with either: respiratory rate $>30 / \mathrm{min}$; severe respiratory distress; or $\mathrm{SpO}_{2}<90.4 \%$ at room temperature, 4) Critical: Complicated by one of the following: Acute Respiratory Distress syndrome or life-threatening organ dysfunction, septic shock and admitted to the intensive care unit (ICU). In statistical analysis, mild and moderate groups were evaluated in a single group as mild-moderate group.

Pulmonary CT findings of the patients were divided into two groups according to the extent of involvement. 1. Mild: Pure ground glass density, number of lesions $\leq 3$ and size of all $\leq 3 \mathrm{~cm}$, 2. Moderate/severe: Pure ground glass density, number of lesions $>3$ and the size of all $>3 \mathrm{~cm}$, consolidation, structural distortion.

\section{Data Collection}

Clinical and laboratory data of the patients were collected from their electronic files. Collected data of patients included age, gender, complaints, comorbidities, laboratory findings, lung CT findings, COVID-19 RT-PCR results, length of stay, ICU hospitalization, clinical results.

\section{Statistical Analysis}

The distribution of data was analyzed using the Shapiro-Wilk test. T-test was used to compare two independent groups with normal distribution. The Mann-Whitney U test was employed to compare two groups that did not show normal distribution. The Fisher Exact test, Pearson chi-square test and Fisher Freeman Halon test were used to compare categorical data. Binary logistic regression analysis with backward stepwise method was used to evaluate the risk factors affecting clinical severity status. Descriptive statistics of the data are given as frequency (percentage), median (minimum-maximum) and mean $[ \pm$ standard deviation (SD)]. All statistical tests were analyzed and 
reported in IBM SPSS Statistics 22.0 program at $\alpha=0.05$ level and $95 \%$ confidence interval.

\section{Results}

$55.4 \%$ of 260 patients included in the study were male $(n=144)$, their mean age was $54.1 \pm 15.5$ years. The three most common symptoms observed in the patients were cough $(71.5 \%)$, fever (55\%) and respiratory distress (35.4\%). Other symptoms were muscle pain $(19.2 \%)$, sore throat $(13.8 \%)$, diarrhea $(11.9 \%)$, and headache $(11.5 \%)$. The three most common comorbidities were HT (39.6\%), diabetes mellitus (DM) (23.6\%) and cardiovascular disease (CVD) (13.1\%), and these were followed by chronic renal failure (CRF) (8.1\%), asthma $(7.3 \%)$ and chronic obstructive pulmonary disease (COPD) (5\%). 56.2\% of the patients $(n=46)$ were in the clinically severe and critical group. In-hospital mortality was $11.9 \%(n=31)$ (Table 1$)$.

The patients were divided into hypertensive $(n=103)$ and nonhypertensive $(n=157)$ groups and their clinical and laboratory characteristics were compared (Table 1,2). Hypertensive patients were older than non-hypertensive patients [mean $( \pm$ SD) 64.6 $( \pm 11.5)$ and $47.2( \pm 13.9)$ years, respectively], rates of DM were higher $(41.7 \%$ and $11.5 \%)$, they were more complicated with CRF (16.5\% vs $2.5 \%)$. Sore throat was statistically significantly lower in the hypertensive group $(6.8 \%$ and $16.5 \%$, respectively,

Table 1. Clinical characteristics of hypertensive and non-hypertensive COVID-19 patients

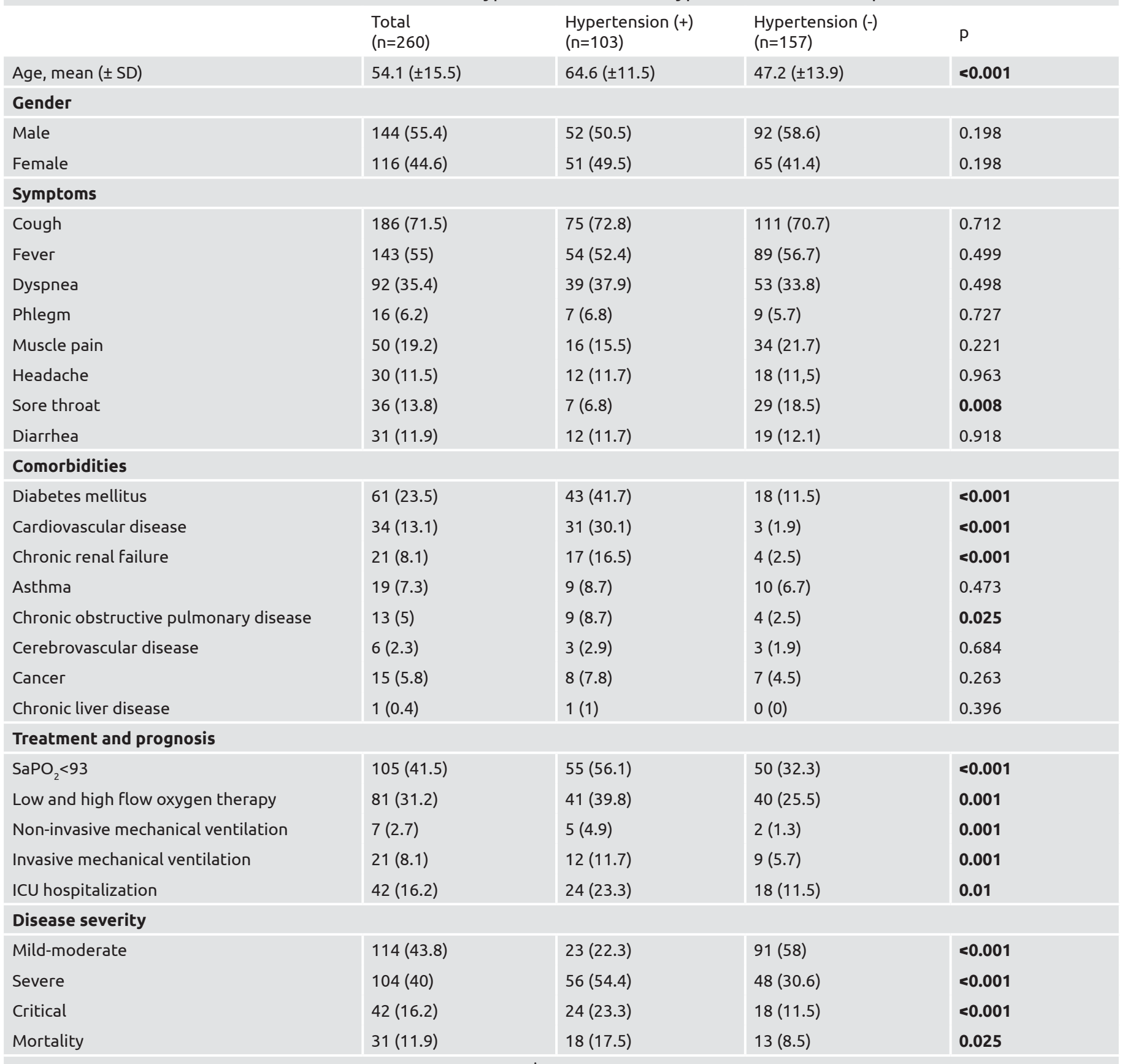

Data are given as mean $( \pm \mathrm{SD}), \%$, SaPO${ }_{2}$ : Hemoglobin oxygen saturation; ICU: Intensive care unit, SD: Standard deviation, COVID-19: Coronavirus disease-2019 
$\mathrm{p}=0.008)$. Cough $(72.8 \%$ and $70.7 \%)$ and dyspnea rates $(37.9 \%$ and $33.8 \%$ ) were higher in the hypertensive group compared to the non- hypertensive group (Table 1).

The $\mathrm{SaPO}_{2}$ (hemoglobin oxygen saturation) value was $<93 \%$ in $41.5 \%(n=105)$ of the patients during hospitalization. While $\mathrm{SaPO}_{2}$ decreased below $93 \%$ in $56.1 \%(\mathrm{n}=55)$ of the patients in the hypertensive group, this rate was $32.3 \%(n=50)$ in the nonhypertensive group $(\mathrm{p}<0.001)$. Considering the clinical severity status, while the rate of patients with severe and critical clinic in the hypertensive group was $77.7 \%$, this rate was $42.1 \%$ in the non-hypertensive group $(\mathrm{p}<0.001)$. Oxygen therapy was required in $39.8 \%$ of hypertensive patients, while this rate was $25.5 \%$ in non-hypertensive patients $(\mathrm{p}=0.001)$. Non-invasive and invasive mechanical ventilation rates were $4.9 \%$ and $11.7 \%$ respectively in hypertensive patients, while these rates were $1.3 \%$ and $5.7 \%$ respectively in non-hypertensive patients, and these differences were statistically significant $(\mathrm{p}=0.001)$. The rate of admission to the ICU in hypertensive patients $(23.3 \%)$ was statistically significantly higher than in the non-hypertensive group $(11.5 \%)$ $(\mathrm{p}=0.01)$. In-hospital mortality rate was statistically significantly higher in hypertensive patients (17.5\%) compared to nonhypertensive patients $(8.5 \%)(\mathrm{p}=0.025)$ (Table 1). While the median (minimum-maximum) value of the hospitalization length of hypertensive patients was 9 days (1-54), this value was 5 days (1-33) in patients without HT $(\mathrm{p}=0.004)$.
Laboratory and imaging results of hypertensive and nonhypertensive patients are shown in Table 2. The median (minimum-maximum) values of neutrophil count, aspartate aminotransferase (AST), lactate dehydrogenase (LDH), and creatinine were significantly higher in hypertensive patients than in non-hypertensive patients. $(\mathrm{p}=0.001 ; \mathrm{p}=0.016 ; \mathrm{p}=0.002$; $\mathrm{p}<0.001$, respectively). Albumin and GFR median values were significantly lower in hypertensive patients $(p=0.002$ and $\mathrm{p}<0.001$, respectively). Severe CT involvement rate was $78 \%$ in hypertensive patients and $67.9 \%$ in the non-hypertensive group. Mild CT findings were detected in $22 \%$ of the hypertensive group and in $32.1 \%$ of the non-hypertensive group ( $\mathrm{p}=0.095)$.

In order to determine the factors affecting the clinical severity status of the patients in our study population, the risk factors for ICU admission were determined by logistic regression analysis. Age, gender, fever, cough, dyspnea, HT, DM, coronary artery disease, COPD, asthma, CRF, saturation rate, and CT severity scoring, which might affect the ICU admission rate, were included in the analysis. As a result of the analysis, age $>65$ years [odds ratio (OR), 1.061; 95\% confidence interval (CI), 1.0261.098; $\mathrm{p}=0.001)$, high fever (OR, 1.655; 95\% CI, 1.034-2.649; $\mathrm{p}=0.036)$, presence of dyspnea (OR, 1.856 ; 95\% CI, 1.148-3; $\mathrm{p}=0.012)$ and saturation $<90 \%(\mathrm{OR}, 3.379 ; 95 \% \mathrm{CI}, 1.548$ 7.377; $\mathrm{p}=0.002$ ) were determined as risk factors for clinical severity. For regression model significance, $\mathrm{p}<0.001$ (Table 3).

Table 2. Comparison of laboratory and computed tomography findings of hypertensive and non-hypertensive COVID-19 patients

\begin{tabular}{|c|c|c|c|}
\hline & $\begin{array}{l}\text { Hypertension (+) } \\
(n=103) \\
\text { Med (min-max) }\end{array}$ & $\begin{array}{l}\text { Hypertension (-) } \\
(n=157) \\
\text { Med (min-max) }\end{array}$ & $\mathrm{p}$ \\
\hline Blood leukocyte count, $\times 10^{3} / u L$ & $6.1(1.06-16.6)$ & $5.3(1.1-13.8)$ & 0.002 \\
\hline Neutrophil count, $\times 10^{3} / u L$ & $4(1.5-14.6)$ & $3.4(0.5-12.4)$ & 0.001 \\
\hline Lymphocyte count, $\times 10^{3} / \mathrm{uL}$ & $1.2(0.2-5.4)$ & $1.3(0.1-3.4)$ & 0.880 \\
\hline Platelet count, $\times 10^{3} / \mathrm{uL}$ & $198( \pm 64)$ & $193( \pm 66.5)$ & 0.526 \\
\hline AST, U/L & $30(10-239)$ & $25(11-141)$ & 0.016 \\
\hline Albumin, $\mathrm{g} / \mathrm{dL}$ & $3.7(2-4.7)$ & $4(1.9-5)$ & 0.002 \\
\hline LDH, U/L & $255(153-977)$ & $242.5(125-770)$ & 0.002 \\
\hline Creatinine, mg/dL & $0.9(0.6-13)$ & $0.8(0.5-7.8)$ & $<0.001$ \\
\hline Serum ferritin, ng/mL & $256(11.6-11.472)$ & $224(2-21.130)$ & 0.136 \\
\hline D-dimer, ng/mL & $260(100-3.940)$ & $245(30-2.195)$ & 0.029 \\
\hline Fibrinogen, mg/dL & $400(145-547)$ & $391(98-832)$ & 0.934 \\
\hline PT, s & $15.8(13.2-40)$ & $15.6(13.6-33.4)$ & 0.248 \\
\hline aPTT, s & $34.4(24.2-80.6)$ & $34.05(24.5-48.9)$ & 0.179 \\
\hline \multicolumn{4}{|l|}{ Computed tomography } \\
\hline Mild , n (\%) & $20(22)$ & $44(32.1)$ & \multirow{2}{*}{0.09} \\
\hline Moderate/severe, n (\%) & $71(78)$ & $93(67.9)$ & \\
\hline
\end{tabular}


Table 3. Logistic regression analysis of risk factors affecting severe clinical rates

\begin{tabular}{|c|c|c|c|}
\hline Variables & Wald & OR $(95 \% \mathrm{Cl})$ & $p$ \\
\hline Age $>65$ & 11.663 & $1.061(1.026-1.098)$ & 0.001 \\
\hline Fever & 4.404 & $1.655(1.034-2.649)$ & 0.036 \\
\hline Presence of dyspnea & 6.366 & $1.856(1.148-3)$ & 0.012 \\
\hline Saturation <\%90 & 9.339 & 3.379 (1.548-7.377) & 0.002 \\
\hline
\end{tabular}

$\mathrm{Cl}$ : Confidence interval, OR: Odds ratio

\section{Discussion}

In our study in which hypertensive and non-hypertensive patients were compared, it was found that the rates of severe clinic, ICU hospitalization and mortality were significantly higher in the hypertensive group. In the logistic regression analysis performed in the study population, age $>65$ years, presence of dyspnea, high fever, saturation $<90 \%$ were determined as risk factors for severe clinic. Previous clinical studies on SARS and Middle East respiratory syndrome patients have shown that HT is a risk factor for increased mortality in infected patients (13-15). Similar results were obtained in many studies conducted with COVID-19 patients (16,17). Cytokine storm seen in COVID-19 patients may be one of the reasons for the increase in disease severity in hypertensive patients. In studies, cytokine storm caused by the increase of cytokines such as IL-6, TNF- $\alpha$, and IL-7 has been found to be associated with clinical worsening of COVID-19 patients $(18,19)$. In some previous studies, it has been shown that the increase in cytokines causes HT to deteriorate (20).

In our study group, the mean age of COVID-19 patients was $54.1 \pm 15.5$ years, and the frequency of HT was $39.6 \%$. In the national cross-sectional epidemiological study in Turkey, HT prevalence in the adult population was determined to be $31.8 \%$ (21). In a study that included 320 COVID-19 patients with a median age of 62 years, HT was found to be at a rate of $36.5 \%$ (12). In another study including 1.099 COVID-19 patients with a median age of 47 years, the prevalence of HT was $15 \%$ (10). It was observed that the prevalence of HT in COVID-19 patients increased in parallel with the increase in the average age of patients. Among the comorbid diseases seen in COVID-19 patients in our study group, DM, CVD and CRF rates were found to be higher in hypertensive patients than in nonhypertensive patients. In previous studies, it was reported that other comorbidities were observed at a higher rate in COVID-19 patients with HT $(12,22)$. It was thought that higher rates of comorbidities and higher average age in hypertensive COVID-19 patients had a negative effect on the prognosis of the disease. The determination of advanced age as a risk factor for severe clinic in the logistic regression analysis performed in the study population supports this.

As in many previous studies $(22,23)$, fever, cough and dyspnea were found to be the most common symptoms in our study. In our study, no significant difference was found in the rates of symptoms between hypertensive patients and non-hypertensive patients. Only sore throat was found to be statistically significantly lower in hypertensive patients. It should be kept in mind that patients may also have gastrointestinal symptoms such as diarrhea, as well as respiratory tract symptoms. In a previous study, it was reported that diarrhea was detected at a higher rate in hypertensive patients compared to non-hypertensive patients (12). In another study conducted with 110 COVID-19 patients, the rate of dyspnea in hypertensive patients was found to be statistically significantly higher (22).

In our COVID-19 patients, the rates of those who were desaturated, those who received oxygen therapy, and those who received non-invasive and invasive mechanical ventilation were higher in hypertensive patients compared to non-hypertensive patients. In a previous study conducted with 310 COVID-19 patients, it was reported that both non-invasive and invasive mechanical ventilation were applied at a higher rate in hypertensive patients (12). In a study involving 2.877 COVID-19 patients, the rate of invasive ventilation in hypertensive patients was significantly higher than in non-hypertensive patients (16).

When we evaluated the laboratory findings of our hypertensive COVID-19 patients, it was found that neutrophil count, AST, LDH and creatinine levels of hypertensive patients were significantly higher than the levels in non-hypertensive patients. The median albumin and GFR values were statistically significantly lower in patients with HT. In a previous study conducted with 310 COVID-19 patients, a significant increase was detected in blood leukocyte and neutrophil count, neutrophil/ lymphocyte ratio, alanine aminotransferase, AST and LDH levels in hypertensive patients compared to non-hypertensive patients (12). In another study, blood leukocyte count was found to be significantly higher in hypertensive patients, but lymphocyte was lower (22).

When we evaluated our patients according to lung CT findings, the rate of moderate/severe CT involvement was found to be higher in hypertensive COVID-19 patients than in nonhypertensive patients, although not significant. In a study in which previously performed lung CTs were evaluated with the scoring system, it was found that lung CT scores were higher in the HT group. Again, in this study, CT scores of the left upper lobe, right upper lobe, right middle lobe and right lower lobe were found to be significantly higher in patients with HT than in patients without HT (17).

Our study has some limitations. The most important limitation is that it is a single center, retrospective study. Other limitation is 
that factors such as smoking and obesity, which might affect the clinical severity of the patients, were not taken into consideration.

\section{Conclusion}

Our study has shown that COVID-19 patients with HT have a more severe clinical course and a poor prognosis. Follow-up and treatment of hypertensive patients should be done more carefully in accordance with current guidelines, considering the risk of poor prognosis.

\section{Ethics}

Ethics Committee Approval: This retrospective observational study was approved by the Bezmialem Vakıf University Ethics Committee.

Informed Consent: Retrospective study.

Peer-review: Externally and internally peer reviewed.

\section{Authorship Contributions}

Concept: G.O., B.D., Y.A., S.B., A.B.K., B.S., H.D.K., M.M.K., Design: G.O., B.D., Y.A., S.B., A.B.K., B.S., H.D.K., M.M.K., Data Collection or Processing: G.O., B.D., Y.A., S.B., A.B.K., B.S., H.D.K., M.M.K., Analysis or Interpretation: G.O., B.D., Y.A., S.B., A.B.K., B.S., H.D.K., M.M.K., Literature Search: G.O., B.D., Y.A., S.B., A.B.K., B.S., H.D.K., M.M.K., Writing: G.O., B.D., Y.A., S.B., A.B.K., B.S., H.D.K., M.M.K.

Conflict of Interest: No conflict of interest was declared by the authors.

Financial Disclosure: The authors declared that this study received no financial support.

\section{References}

1. Zhou F, Yu T, Du R, Fan G, Liu Y, Liu Z, et al. Clinical course and risk factors for mortality of adult inpatients with COVID-19 in Wuhan, China: a retrospective cohort study. Lancet . 2020;395:1054-62.

2. World Health Organization. Coronavirus disease (COVID-19). Situation report 142. June 2020 [June 2020]. Available from: https://www.who.int/docs/default-source/coronaviruse/situationreports/20200610-covid-19-sitrep-142.pdf?sfvrsn=180898cd_2.

3. Wu C, Chen X, Cai Y, Xia J, Zhou X, Xu S, et al. Risk Factors Associated With Acute Respiratory Distress Syndrome and Death in Patients With Coronavirus Disease 2019 Pneumonia in Wuhan, China. JAMA Intern Med 2020;180:934-43.

4. Wu JT, Leung K, Bushman M, Kishore N, Niehus R, de Salazar PM, et al. Estimating clinical severity of COVID-19 from the transmission dynamics in Wuhan, China. Nat Med 2020;26:506-10.

5. Zhou P, Yang XL, Wang XG, Hu B, Zhang L, Zhang W, et al. A pneumonia outbreak associated with a new coronavirus of probable bat origin. Nature 2020;579:270-3.

6. Lu R, Zhao X, LiJ, Niu P, Yang B, Wu H, etal. Genomiccharacterisation and epidemiology of 2019 novel coronavirus: implications for virus origins and receptor binding. Lancet 2020;395:565-74.
7. Hamming I, Timens W, Bulthuis ML, Lely AT, Navis G, van Goor $\mathrm{H}$. Tissue distribution of ACE2 protein, the functional receptor for SARS coronavirus. A first step in understanding SARS pathogenesis. J Pathol 2004;203:631-7.

8. Jia HP, Look DC, Shi L, Hickey M, Pewe L, Netland J, et al. ACE2 receptor expression and severe acute respiratory syndrome coronavirus infection depend on differentiation of human airway epithelia. J Virol 2005;791:14614-21.

9. Wang D, Hu B, Hu C, Zhu F, Liu X, Zhang J, et al. Clinical characteristics of 138 hospitalized patients with 2019 novel coronavirus-1nfected pneumonia in Wuhan, China. JAMA 2020;323:1061-9.

10. Guan WJ, Ni ZY, Hu Y, Liang WH, Ou CQ, He JX, et al. Clinical characteristics of coronavirus disease 2019 in China. N Engl J Med 2020;382:1708-20.

11. Yan R, Zhang Y, Li Y, Xia L, Guo Y, Zhou Q. Structural basis for the recognition of SARS-CoV-2 by full-length human ACE2. Science 2020;367:1444-8.

12. Altun B, Arici M, Nergizoglu G, Derici Ü, Karatan O, Turgan Ç, et al. Prevalence, awareness, treatment and control of hypertension in Turkey (the PatenT study) in 2003. J Hypertension 2005;23:181723.

13. Huang S, Wang J, Liu F, Liu J, Cao G, Yang C, et al. COVID-19 patients with hypertension have more severe disease: a multicenter retrospective observational study. Hypertens Res 2020:1-8.

14. Hui DS, Azhar EI, Madani TA, Ntoumi F, Kock R, Dar O, et al. The continuing 2019-nCoV epidemic threat of novel coronaviruses to global health - The latest 2019 novel coronavirus outbreak in Wuhan, China. Int J Infect Dis 2020;91:264-6.

15. Zhou X, Zhu J, Xu T. Clinical characteristics of coronavirus disease 2019 (COVID-19) patients with hypertension on renin-angiotensin system inhibitors. Clin Exp Hypertens 2020;42:656-60.

16. Gao C, Cai Y, Zhang K, Zhou L, Zhang Y, Zhang X, et al. Association of hypertension and antihypertensive treatment with COVID-19 mortality: a retrospective observational study. Eur Heart J 2020;41:2058-66.

17. Wang S, Chen Y, Wang L, Liu H, Han P. Are COVID-19 patients with hypertension at higher risk in China? J Hypertens 2020;38:1384-5.

18. Morra ME, Van Thanh L, Kamel MG, Ghazy AA, Altibi AMA, Dat LM, et al. Clinical outcomes of current medical approaches for Middle East respiratory syndrome: A systematic review and metaanalysis. Rev Med Virol 2018;28:e1977.

19. Matsuyama R, Nishiura H, Kutsuna S, Hayakawa K, Ohmagari $\mathrm{N}$. Clinical determinants of the severity of Middle East respiratory syndrome (MERS): a systematic review and meta-analysis. BMC Public Health 2016;16:1203.

20. Kreutz R, Algharably EAE, Azizi M, Dobrowolski P, Guzik T, Januszewicz A, et al. Hypertension, the renin-angiotensin system, and the risk of lower respiratory tract infections and lung injury: implications for COVID-19. Cardiovasc Res 2020;116:1688-99.

21. Qin C, Zhou L, Hu Z, Zhang S, Yang S, Tao Y, et al. Dysregulation of immune response in patients with COVID-19 in Wuhan, China. Clin Infect Dis 2020;71:762-8. 
22. Chen G, Wu D, Guo W, Cao Y, Huang D, Wang H, et al. Clinical and immunological features of severe and moderate coronavirus disease 2019. J Clin Invest 2020;130:2620-9.
23. Drummond GR, Vinh A, Guzik TJ, Sobey CG. Immune mechanisms of hypertension. Nat Rev Immunol 2019;19:517-32. 